\title{
ORGANIZING WASTE THROUGH COMMUNITY PARTICIPATION IN NAPA VILLAGE
}

\author{
Indah Kusuma Dewi ${ }^{1}$ \\ ${ }^{1}$ Legal Studies Program, Faculty of Law Universitas Muhammadiyah Buton \\ e-mail: indahkusumamh@gmail.com
}

\begin{abstract}
The community should be more aware of managing waste by sorting organic and non-organic waste and understanding how to manage Reuse Reduce Recycle (3R) Waste so that the waste problem in Napa Village can be overcome. The objectives to be achieved through community service and outreach activities are as follows: (1) To increase public awareness about the importance of waste management in Napa Village; (2) to find out the factors that become obstacles in waste management in napa village; (3) Increased understanding, community development efforts on the importance of preserving the environment; (4) Increased understanding of the community in efforts to foster institutions and professional societies in the face of modernization in their lives. The results obtained from the community service activities are: (1) Organizing waste in Napa Village is identification of problems related to waste management in Napa Village, socialization of the concept of 3R Trash, counseling on how to treat waste, surveying the location of waste disposal sites and identification of waste management institutions; (2) The concept of the implementation of waste management, namely the construction of temporary landfills/waste bins, the creation of the final landfill site for Napa Village, the establishment of the Napa Village Waste Management Institute, the provision of garbage transport equipment, the separation of waste with the $3 \mathrm{R}$ concept and the use of the 3R Waste Technology, with this activity the people of Napa Village no longer throw garbage in the sea, but in the place that has been provided.
\end{abstract}

Keywords: Waste Management, Community Participation, 3R Concept

\section{A. Introduction}

Efforts to preserve nature amid various community activities must be the responsibility of all parties. In accordance with the mandate of the 1945 Constitution Article $28 \mathrm{H}$ paragraph (1) states that it gives the right for everyone to get a good and healthy environment. A clean environment with good garbage processing can encourage the realization of a healthy and prosperous society in the future. This can be realized if there is community awareness starting from each individual. At least by paying attention to how to manage each other's household waste. 
Waste is a common problem, it can be observed simply the factors that cause the increase in the volume of waste that is, Changes in community consumption patterns and population growth resulting in an increase in the volume, type, and characteristics of various waste. The Central Statistics Agency (CSA) estimates that Indonesia will enjoy the era of demographic bonus in 2020-2035. At that time, the population of productive age is projected to be on the highest graph in history, reaching 64 percent of the total population of Indonesia, which amounted to 297 million people. Indonesia's demographic bonus, of course, must be viewed from a variety of perspectives, not only in the readiness of the state to provide employment for high-productive age partners, but also to prepare and take into account the nature and nature of the Indonesian motherland always in a livable condition.

Each increase in population will be a logical consequence of increasing the amount of waste. The composition of waste generated from human activities is 60-70\% organic waste and the rest is 30-40\% non-organic waste, while the second highest composition of nonorganic waste is $14 \%$ is plastic waste. Most plastic waste is a type of plastic bag or plastic bag in addition to plastic packaging. Indonesia ranks second in the world after China produces plastic waste in waters reaching 187.2 million tons. This relates to data from the Ministry of Environment and Forestry which states that the plastic produced from 100 shops or members of the Indonesian Retail Business Association within just one year, has reached 10.95 million pieces of plastic bag waste. The number was apparently equivalent to an area of 65.7 hectares of plastic bags. (Sulistiawan, 2008)

The second rank of waste producer in the world, proves that Indonesian citizens are not good in terms of managing waste. Law number 18 of 2008 concerning waste management, in article 5 states "The government and regional governments are tasked with ensuring the implementation of good and environmentally sound waste management in accordance with the objectives as referred to in this Law". Although the guarantee for the implementation of good waste management is borne by the government and regional governments, it is the collective awareness of the community, and all parties, that can realize good waste management.

Without the participation of waste-producing communities, all planned waste management programs will be in vain. One approach to the community to be able to help government programs in cleanliness is how to familiarize the community with behavior that is consistent with the program's objectives. This includes, among others, how to change 
people's perception of orderly and orderly waste management, social factors, structure and local culture, habits in waste management so far. (Damanhuri \& Padmi, 2008).

\section{B. Problems}

Community service this time to increase public awareness of waste management in Napa Village, the formulation of the problem in Community Service at Napa Village is:

1. How is the organization of community awareness in waste management in Napa Village?

2. What is the concept of implementing the Village Regulation on Waste Management in Napa Village?

\section{Implementation Method}

The implementation of community service activities is carried out with several methods, namely:

1. The method of socialization by giving guidance to the community on the importance of waste management in order to improve understanding and quality of life of the community for the realization of an environmentally conscious village, followed by discussions to obtain results and accordingly as a form of problem solving and control faced.

2. The method of discussion with the community in Napa Village about what factors are obstacles in realizing Napa Village as an environmentally conscious and quality village in waste management.

The method used in community service activities is through lectures, discussions by identifying case by case (Hardin, 2019: 32).

\section{Discussion}

\section{Organizing Community Participation in Waste Management in Napa Village}

The Partner Village Development Program in Napa Village for the first phase is organizing community participation to manage waste so as to create a healthy Village Community Development. The method used is counseling and outreach to the community and government officials in Napa Village so that they can understand how to organize in managing waste in Napa Village.

a. Identification of problems related to waste management in Napa Village 
1. There is no public awareness in managing waste and littering. The people of Napa Village mostly throw trash on the beach because of the location of Napa Village which is near the open sea on Buton Island. Waste dumped on the seafront will then be swept by sea water and into the sea. Thus, any rubbish that is dumped on the seafront will be lost carried by the flow of sea water and carried to the middle of the sea, so that there is never a buildup of rubbish on the seafront. On one side there is no accumulation of rubbish on the seafront, but when garbage is carried to the middle of the sea it will be very dangerous for marine life, especially dangerous or toxic waste and plastic waste that cannot be destroyed.

2. Facilities and infrastructure for waste management in Napa Village are not yet available such as: (a) Temporary Disposal Sites; (b) Final Disposal Sites; (c) waste transport equipment; (d) Waste processing technology.

3. Waste management institutions have not yet been formed

4. Village Regulation on Waste Management does not yet exist.

b. Socialization of the $3 \mathrm{R}$ Trash Concept

In the Law of the Republic of Indonesia Number 18 Year 2008, it is said that the waste problem includes many aspects, therefore its management needs to be carried out comprehensively and integrated with new innovations that are more adequate in terms of all aspects, both social aspects, economic aspects as well as technical aspects from upstream to downstream in order to provide economic benefits, be healthy for the environment, and be able to change people's behavior, meaning that waste handling needs to be done from the source. Community-based waste management with the $3 \mathrm{R}$ concept aims to reduce waste from its source, reduce environmental pollution, provide benefits to the community, and can change people's behavior towards waste. The $3 \mathrm{R}$ concept is actually very simple and easy to implement, but difficult to implement. Because the success of the $3 \mathrm{R}$ concept is largely determined by community participation by changing its behavior which is generally influenced by the socio-cultural and socio-economic character that characterizes people's lives. For this reason, a paradigm shift in waste management is needed from now on. Community involvement in waste management is one of the key factors to overcome the problem of urban waste. Application of the $3 R$ concept in managing waste independently by the community is not new in waste management. However, the implementation of community-based waste management with 
the $3 \mathrm{R}$ concept must begin by changing the behavior of "disposing" of waste to the behavior of "managing" waste.

2. Counseling on Waste Processing Methods

Ways and Techniques of Waste Management can be defined as a field relating to the control of waste dumps, storage, collection, transfer and transportation, processing, and disposal of waste in a manner that is in accordance with the best principles relating to public health, economics, engineering, nature protection, beauty and other environmental considerations and consider the wider community. According to Article 1 number (1) of Law Number 18 Year 2008 concerning Waste Management, the definition of waste is the residual daily activities of humans and / or natural processes in the form of solid. Whereas according to Article 1 number (5) Waste management is a systematic, comprehensive, and sustainable activity which includes the reduction and handling of waste. So that management in urban areas, today faced with various problems that are quite complex. These problems include the high rate of landfill waste, public concern (human behavior) which is still very low and problems in the activity of final disposal. Besides that, in urban society there is a consumptive culture that influences the improvement of the quality and type of waste, so that waste management cannot be separated from the interference of the state and various sectors in society including the business world. In addition, the role of the community which is a network or community of garbage disposal also has a big role in waste management in this case the recycling process to be reused. So that in waste management is part of public services that must be regulated in regulations that are expected to provide comfort in the daily lives of citizens.

Green city is an environmentally friendly city, where one of the instruments is waste management. To carry out these activities, a green community was formed, in an effort to improve the quality and quantity of the environment. This program can run well if it involves the socio-cultural potential that exists in the community, including local wisdom that is social capital. For the realization of a green city, the Ministry of Public Works rolled out P2KH, while the Ministry of Environment rolled out the Waste Bank program, which is one of the assessment instruments for the city of "Adipura".

3. Identification of Waste Service Standards

The administration of government in general has two main functions, namely: the regulatory function and the service function. Whatever the shape and the extent of the 
territory, it will not be able to hold centralized government continuously. This limited capacity of government has logical consequences in the form of the distribution of state government affairs to regional governments. This condition is in line with the demands of the Indonesian Constitution

In 1945 the fourth amendment that the administration of Indonesian government was carried out was also based on the principle of decentralization. The concept of decentralization is implemented in the form of granting the widest possible autonomy to the regions to take care of their own government affairs based on the authority that has been handed over to the regions into their own household affairs.

The concepts and important dimensions of public services include the following: 1 . Services without discrimination from public institutions/services. 2. Application of the principles of simplicity, clarity, certainty, security, openness, efficiency, economy, fair equity and timeliness.3. Quality in the sense of conformity with demands, compatibility with the use of freedom from disability. 4. Touchable, reliable, accountability, quality of service, assurance, and empathy. 5. Oriented to modern quality characterized by active participation and empathy and satisfaction served.

Some of the essentials in the delivery of public services that need to be realized are:

1. There is an obligation on the part of the state administration to carry out its functions and authorities based on the principles of good and clean governance;

2. Recognition of the rights of every citizen to good governance and administrative behavior;

3. Diversity of types and scope of implementation of public services in Indonesia as a result of the diversity of affairs and interests of the community that must be met through the administration of public services;

4. Survey of the location of the landfill

Surveying the location of the landfill is to determine the position of the place where the temporary and final landfills have been built, given that there are often complaints from residents about the existence of the place, so that with the survey it is expected that land problems will not occur in the future. This survey was conducted by a team and assisted by all students.

5. Identification of Waste Management Institution

The organizational and management aspect is a multi-disciplinary activity that relies on technical and management principles that concern the economic, social, cultural, and 
physical conditions of the city area, and pay attention to the parties served, namely the urban community. The design and selection of organizational forms are adjusted to:

a. Government regulations that build it

b. The operational system pattern applied

c. System work capacity

d. The scope of work and tasks must be handled.

6. Concept of Implementation of Napa Village Regulation Regarding Waste Management

The construction of temporary landfills is carried out at a place that has been provided by the residents of Napa Village as a place to temporarily store the garbage before being transported to the final landfill.

a. Making the location of the Napa Village Waste Disposal Site

The construction of a landfill is carried out at the location determined by the Decree of the Head of the Napa Village.

b. Establishment of Napa Village Waste Management Institution

A waste management institution was formed to manage the service of paying waste fees and managing waste collection from temporary landfills to landfills.

c. Provision of garbage transport equipment

Garbage transport equipment can be in the form of trucks, pick-up trucks or garbage carts, depending on the village's ability to procure these cars.

d. Waste separation with $3 \mathrm{R}$ concept

Separation of waste with the $3 \mathrm{R}$ concept is very important to be able to sort out which waste cannot be recycled and which waste can be recycled.

e. Use of Garbage 3R Technology

The use of 3R technology aims to be able to utilize waste that can still be recycled and for waste that can be composted it is necessary to immediately hoard it in order to reduce air pollution so that the environment will be healthy. In addition, waste recycling technology will benefit economically and can even increase people's income.

\section{E. Conclusion}

The conclusions of community service activities are: (1) Organizing waste in Napa Village is identification of problems related to waste management in Napa Village, socialization of the 3R Concept of Garbage, counseling on how to treat waste, surveying the 
location of waste disposal sites and identification of waste management institutions; (2) The concept of the implementation of waste management is the creation of temporary landfills / garbage bins, the creation of the final landfill site for Napa Village, the establishment of the Napa Village Waste Management Institute, the provision of garbage transport equipment, the separation of waste with the $3 \mathrm{R}$ concept and the use of the 3R Garbage Technology.

\section{BIBLIOGRAPHY}

Damanhuri, E., \& Padmi, T. (2008). Diktat Kuliah Pengelolaan Sampah Bagian 4: Kegiatan Daur Ulang Sampah Di Indonesia. Diktat Program Studi Teknik Lingkungan Institut Teknologi Bandung.

Hardin. (2019). Pembinaan Pengurus Persaudaraan Beladiri Kempo Indonesia (Perkemi) Dojo Sorawolio Dalam Melaksanakan Peran dan Fungsi Manajemen Organisasi. Jurnal Pengabdian Kepada Masyarakat MEMBANGUN NEGERI Vol. 2 No.1 April 2019. hal 27-36

Sulistiawan, I. N. (2008). Pengelolaan Sampah Secara Terpadu di Perumahan Pamungkas.

Undang-Undang Dasar Negara Republik Indonesia Tahun 1945

Undang-Undang Nomor 18 tahun 2008 tentang Pengelolaan Sampah 